\title{
PENYELENGGARAAN PEMBANGUNAN DESA DI DESA BIKA NAZARET
}

\author{
Petrus Atong \\ Fakultas Ilmu Sosial dan Ilmu Politik Universitas Kapuas Sintang \\ Jln. Oevang Oeray Nomor 92 Baning Kota Sintang \\ Email: atong-petrus@gmail.com
}

\begin{abstract}
Abstrak: Pelaksanaan dan penyelengaraan pembangunan di desa, antara lain menjadi salah satu fungsi dan tanggung jawab kepala desa. Peranan penting pelaksanaan pembangunan di desa adalah Kepala Desa harus mampu meningkatkan kegiatan koordinasi dan partisipasi masyarakat dan badan perwakilan desa untuk bersatu padu melaksanakan pembangunan di desa. Pelaksanaan pembangunan desa yang telah dilakukan berupa peningkatan koordinasi, sosialisasi pemeliharaan hasil pembangunan serta peningkatan partisipasi dalam perencanaan, pelaksanaan pemanfaatan dan pemeliharaan hasil pembangunan desa. Aspek penting seperti keikutsertaan dalam perencanaan, pelaksanaan, pemeliharaan dan pemanfaatan hasil pembangunan.
\end{abstract}

Kata Kunci: Penyelenggaraan, pembangunan, desa.

Keberhasilan pembangunan di berbagai sektor pembangunan daerah sampai pada tingkat pedesaan menjadi perhatian khusus pemerintah karena desa merupakan mata rantai dalam sistem kepemerintahan Indonesia. Pola pembangunan yang dilaksanakan menerapkan konsep kebersamaan dengan istilah gotongroyong, atau partisipasi atau keikutsertaan masyarakat dalam pembangunan (Tjokroamidjojo,1998:222-226). Mengingat pentingnya partisipasi / gotongroyong atau keikutsertaan masyarakat dalam pembangunan, maka dapat dikatakan bahwa pelaksanaan pembangunan, yang meliputi segala segi kehidupan masyarakat baru akan berhasil apabila pembangunan merupakan kegiatan yang melibat partisipasi dari seluruh anggota masyarakat baik sejak dari perencanaan maupun sampai menikmati hasil atau pemeliharaan hasil pembangunan itu (Kuswata,1985:21)

Dalam pembangunan khususnya pembangunan desa masyarakat menjadi subyek dan obyek pembangunan, maka keterlibatan mereka dalam pembangunan desa didesa mempunyai kedudukan yang sangat penting demi berhasilnya pembangunan itu. Menurut Ndraha (2002:38) bahwa pemerintah berkedudukan dan berperan sebagai pembina masyarakat karena pada umumnya kemampuan masyarakat untuk berkedudukan dan berperan sebagai subyek pembangunan tampaknya masih rendah atau kurang, pengembangan pembangunan di desa, melalui peran keikutsertaan masyarakat adalah untuk mengembangkan perencanaan pembangunan melalui ide-ide sistem perencanaan dari bawah atau bottom up planning ( Ndraha,T, 2002:111)

\section{METODE PENELITIAN}

Penelitian deskriptif kualitatif merupakan penelitian yang termasuk dalam jenis penelitian kualitatif. Subjek penelitian adalah sumber utama data penelitian, yaitu yang memiliki data mengenai permasalahan - permasalahan yang diteliti. Subjek penelitian adalah Kepala Desa Bika Nasaret. Teknik pengumpulan data yang ditetapkan adalah wawancara, observasi, dokumentasi. Analisis data merupakan proses penyederhanaan data kedalam bentuk yang lebih mudah dibaca dan di interprestasikan.

\section{HASIL DAN PEMBAHASAN}

Salah satu tolak ukur keberhasilan pembangunan adalah tersedianya keikutsertaan atau partisipasi seluruh masyarakat dalam pembangunan itu sendiri. Penyelenggaraan pembangunan desa, diketahui bahwa pemerintah desa, melalui peranan kepala desa serta peranan badan perwakilan desa telah berusaha secara baik dengan melibatkan keikutsertaan warga masyarakat dalam penyelenggaraan pembangunan di desa (Marbun, 2000:214). Penyelengaraan pembangunan ( Sawe,1996;79) di desa Bika Nazaret ditampilkan dengan berbagai keikutsertaan warga masyarakat dalam proses pembangunan seperti dalam ide-ide perencanaan, pelaksanaan, pemanfaatan dan pemeliharaan hasil pembangunan (Muhi,2011:87). 
Keikutsertaan masyarakatdalam perencanaan pembangunan (Moeljarto, 1997:89., Slamet, 2003:56) di desa diketahui bahwa belum seluruhnya ide penyusunan rencana pembangunan di desa dimusyawarahkan dengan anggota warga masyarakat, sedangkan intensitas keikutsertaan masyarakat dalam menyusun ide perencanaan pembangunan belum dapat terlibat semua. Sikap persetujuan warga masyarakat terhadap hasil penyusunan ide perencanaan pembangunan di desa, sebagian besar dapat disetujui dan diterima oleh warga masyatakat, antara lain ide rencana pembangunan di desa, seperti jalan desa, rumah pos penjagaan, perumahan balai desa, pengadaan air minum bersih keluarga dan pembangunan sarana dan prasarana mandi cuci dan kakus keluarga.

Keikutsertaan masyarakat dalam pelaksanaan pembangunan (Beratha,1996:113) di desa diketahui bahwa sebagian besar warga masyarakat yang sudah ditetapkan sebagai yang terlibat dalam pelaksanaan pembangunan desa, telah terlibat dengan baik dan selalu aktif setiap pelaksanaan kegiatan pembangunan yang sedang dilakukan, seperti terlibat membuat jalan desa, pos penjagaan dan pembenahan lingkungan mandi cuci dan kakus milik keluarga. Dalam posisi yang demikian sebagian besar warga masyarakat menyadari bahwa keterlibatan atau keikutsertaan mereka dalam pelaksanaan pembangunan di desa sangat penting, mereka berpendapat bahwa mereka sebagai penentu keberhasilan dan ketidak keberhasilan kegiatan pembangunan di desa yang sedang dilaksanakan.

Keikutsertaan masyarakat dalam memanfaatkan hasil - hasil pembangunan Supratna, 1986:55., Sutrisno, 1996: 224) di desa, diperoleh gambaran bahwa warga masyarakat yang terlinbat dalam perencaan,dan pelaksanaan pembangunan di desa, maka mereka juga tetap bertanggungjawab atas pememanfaatan hasil-hasil pembangunan yang telah selesai dibangun. Timbul rasa tanggungjawab dalam memanfaatkan hasil pembanguna telah diawali dengan keikutsertaan mereka sejaka awal dalam hal perumusan ide rencana pembangunan dan keikutsertaan mereka dalam pelaksanaan pembangunan itu, terutama dalam hal ini seperti pemanfaatan balai desa dan pos penjagaan keamanan masyarakat.

Keikutsertaan masyarakat dalam pemeliharaan pembangunan (Marbun,2000:214) di desa, timbul rasa tanggungjawab masyarakat terhadap pembangunan diawali karena adanya kesadaran dan pengertian akan maksud dan tujuan pembangunan yang selanjutnya timbul kesadaraan untuk ikutserta dalam perencanaan dan pelaksanaan pembangunan, hasil-hasil pembangunan dan yang pada akhirnya akan memunculkan kesadaran mereka untuk memelihara hasil pembangunan di desa telah dilaksanakan sesuai dengan kebutuhan dan kepentingan masyarakat dapat termanfaatkan dan dipelihara sebagaimana mestinya. Dari hasil penelitian diketahui bahwa sebagian besar warga masyarakat Bika telah memiliki kesadaran dengan tetap memilihara sebagian hasil pembangunan yang menjadi tugas mereka, serta mereka juga ikutserta memelihara hasil pembangunan yang menjadi tugas pemerintah desa seperti Balai Desa dan jalan desa.

Dengan kesempatan keikutsertaan warga masyarakat dengan berbagai aktivitas pembangunan di desa, diharapkan akan menimbulkan rasa tanggungjawab masyarakat terhadap hasil pembangunan di desa yang dalam hal ini warga masyarakat bertanggungjawab terhadap pemeliharaan pembangunan yang dibiayai dengan dana anggaran desa. Masyarakat desa Bika dalam tanggungjawabnya terhadap hasil pembangunan desa ditunjukan dengan penjagaan atau pemeliharaan mereka terhadap hasil pembangunan desa yang telah dicapai. Kondisi hasil pembangunan yang dilaksanakan sesuai dengan ide dan kebutuhan warga masyarakat (Sutrisno,1995:225) terlihat sangat dimanfaatkan dan dipelihara dengan baik, kondisi ini juga menunjukan bahwa hasil pembangunan fisik cendrung bertahan lama dan tetap terjaga atau terawat dengan baik.

\section{KESIMPULAN DAN SARAN}

Penyelenggaraan pembangunan desa di desa Bika Nazaret, dengan melibatkan kesadaran masyarakat yang bertujuan bertanggunjawab dalam proses pembangunan, telah ditunjukan dengan keikutsertaan warga masyarakat dalam ide perencanaan, pelaksanaan, pemanfaatan hasil serta pemeliharaan hasil pembangunan. Keikutsertaan warga masyarakat dalam berbagai kegiatan oleh pemerintah desa, telah menunjukan kesadaran mereka dalam penyelenggaraan pembangunan di desa. Keikutsertaan warga masyarakat dalam ide perencanaan sampai dengan tanggungjawab pemeliharaan hasil pembangunan telah dilakukan dengan baik, benar dan sangat memuaskan. Saran yang disampikan adalah, pola kerja selalu melibatkan warga masyarakat tetap terus ditingkatkan melalui kegiatan musyawarah rapat desa, rapat dusun dan rapat rukun tetangga, kelemahan dalam penyusunan rencana pembangunan atau teratasi dengan kekuatan hubungan kerja warga desa dan kekompakan memandang arti pentingan kebutuhan akan pembangunan yang sedang dan yang akan dilaksanakan. 


\section{DAFTAR PUSTAKA}

Beratha, 1996. Desa, Masyarakat Desa dan Pembangunan. Jakarta: Ghalia Indonesia.

Hasibuan, Malayu. 2002. Manajemen Sumber Daya Manusia.Jakarta: Bumi Akasara

Kuswata, A.1985: Manajemen Pembangunan Desa, Grafindo Utama, Jakarta.

Moeljarto,T.1997.Politik Pembangunan, Sebuah Analisis, Arah dan Strategi. Yogyakarta: Tiara Wacana Yogya.

Muhi, Ali Hanapiah, 2011. Perencanaan Pembangunan Desa. Jatingor: Alqa Prisma Interdelta.
Marbun, 2000.Proses Pembangunan Desa, Menyongsong Tahun 2000.Surabaya: Erlangga

Ndraha, T. 2002. Membangun Masyarakat Mempersiapkan Masyarakat Tinggal Landas. Jakarta: Rineka Cipta.

Sawe, Jamaluddin. 1996. Konsep Dasar Pembangunan Pedesaan. Bandung: APDN Press.

Slamet, M. 2003. Membentuk Pola Perilaku Manusia Pembangunan. Bogor: IPB Press.

Sutrisno, L. 1995. Menuju Masyarakat Partisipatif. Yogyakarta: UGM Press.

Tjokroamidjojo. 1998. Pengantar Administrasi Pembangunan. Jakarta: LP3ES 